\title{
Election Administration During Natural Disasters and Emergencies: Hurricane Sandy and the 2012 Election
}

\author{
Robert M. Stein
}

\begin{abstract}
What steps can and do local election officials take to prepare for and respond to natural disasters and emergencies that impede and disrupt the operation of scheduled elections? How efficacious are these actions and practices, and to what extent, if any, can these practices be generalized to the 3,000+ jurisdictions charged with conducting elections? In this article I address these questions by examining the conduct of the 2012 presidential election in the aftermath of Hurricane Sandy. I find several correctives for the disruptive effect of emergencies and natural disasters on voter participation including state laws that afford voters opportunities to ballot before Election Day and the number and staffing of polling places. These correctives provide clear guidance for the conduct of elections outside of natural disasters and emergencies.
\end{abstract}

\section{INTRODUCTION}

W HAT STEPS CAN AND DO state and local election officials take to prepare for and respond to natural disasters and emergencies that impede and disrupt the operation of scheduled elections? How efficacious are these actions and practices, and to what extent, if any, can these practices be generalized to nearly 3,000 jurisdictions charged with conducting elections? In this article I address these questions by examining the conduct of the 2012 presidential election in the aftermath of Hurricane Sandy. Hurricane Sandy made U.S. landfall on October 29, 2012 affecting 24 states, including the entire eastern seaboard between Florida and Maine, with particularly severe damage in New Jersey and New York. The Federal Emergency Management Agency (FEMA) issued disaster declarations ${ }^{1}$ in 225 U.S. counties in ten states. ${ }^{2}$ It is in these counties that we might expect to observe Sandy's impact on balloting in the 2012 election

Robert M. Stein is a professor of political science at Rice University in Houston, TX. and the mitigating effects, if any, state and local practices had on the Sandy's impact on voter participation in the 2012 election.

The negative effect Hurricane Sandy had on voter participation was significantly muted in those states that afforded their voters opportunities to vote before Election Day i.e., early in-person voting and no-excuse mail-in voting. The incidence of these voting options in counties adversely affected by Hurricane Sandy was limited to a few states. Moreover, the authority to exercise these voting options resides with state legislatures, not local election officials. Local election officials do have authority over polling place locations, operations, and staffing. I find that a small number of larger

\footnotetext{
${ }^{1}$ A disaster declaration by the Federal Emergency Management Agency (FEMA) enables jurisdictions within an affected area to receive federal assistance for recovery efforts. I use this designation as means of identifying those counties most adversely affected by Hurricane Sandy and likely to have experienced the greatest disruption to the conduct of the 2012 election. ${ }^{2}$ Connecticut, Delaware, Maryland, New Hampshire, New Jersey, New York, Rhode Island, Pennsylvania, Virginia, and West Virginia.
} 
Election Day polling place locations significantly mitigated the negative effect Hurricane Sandy had on voter turnout in the 2012 election.

\section{REMEDIES FOR THE POTENTIAL EFFECT OF EMERGENCIES ON THE CONDUCT AND ADMINISTRATION OF ELECTIONS}

A majority (63\%) of voters in U.S. elections are required to cast their ballots on Election Day and at only one precinct polling location which is most proximate to their residence (Pew 2012). Natural disasters and emergencies on or before Election Day suppress voter participation, particularly among voters with a history of infrequent voting and Election Day voters. This condition is largely brought about by inaccessible voting places, voters and poll workers who are unable to get to polling places, and polling places that are damaged and/or inoperable (e.g., lack power). Election administrators' responses to natural and man-made emergencies come in two forms: alternative modes of voting and how local election officials locate, staff, and equip their Election Day polling places.

Four modes of voting other than Election Day precinct balloting may help to mitigate the effects of severe weather and emergencies on the conduct of elections and voter participation. These include: mail-in voting, in-person early voting, Election Day vote centers, and provisional voting. Each of these different modes of voting affords both voters and election officials significant flexibility and convenience to cast a ballot that might not be otherwise be possible as a result of severe weather or other emergency.

Mail-in voting is available in all 50 states. Noexcuse mail-in voting is allowed in 27 states, and eight states have permanent mail-in voting, where voters are sent a mail-in ballot and do not have to request one for each election (NCSL 2012). First adopted by Texas in 1989 in-person early voting, available in 32 states, allows voters to cast ballots days and weeks before Election Day. Voters are not limited to balloting at only one location as on Election Day (Stein 1994; Gronke and Toffey 2008). Voters are afforded an opportunity to vote at a number of locations, many of which are central to where voters work, shop, recreate, and travel in the course of a weekday or weekend. Early voters are given a residentially appropriate ballot for where they live (Stein and Garcia-Monet 1997). Election Day vote centers, first adopted in Larimer, Colorado in 2004 (Stein and Vonnahme 2008) similarly allow Election Day voters to ballot at any number of locations throughout the jurisdiction. These centers are often more convenient than residentially based polling locations. As with in-person voting, voters at Election Day vote centers are not required to vote at only one location. Wherever they choose to cast their ballot voters balloting at an Election Day vote center are given a residentially appropriate ballot. Under the provisions of the 2002 Help American Vote Act (HAVA) there are opportunities for persons deemed ineligible to vote to cast a provisional ballot. A provisional ballot is used to record a vote when there are questions concerning the voter's eligibility, for example a lack of proper identification, lost during severe weather, or voting at the wrong polling place because the voter's Election Day polling was inaccessible. Whether a provisional ballot is counted is contingent upon verification of the voter's eligibility determined by local election officials several days after Election Day.

Each of these alternative modes of votingabsentee mail-in, in-person early, Election Day vote center and provisional voting-provides the voter and local election official with varying degrees of flexibility to cast a ballot before or even after severe weather or other natural disaster/emergency has threatened or disrupted the normal conduct of an election. Opportunities to cast a ballot before severe weather threatens an election are limited by state law. Moreover, an overwhelming majority of those states which experienced the most severe effects of Hurricane Sandy did not afford their voters

Table 1. Laws Regulating Absentee and Early Voting Among States with One or More Counties

That Received a Disaster Declaration in 2012

\begin{tabular}{lcc}
\hline State & $\begin{array}{c}\text { No-excuse } \\
\text { absentee mail-in }\end{array}$ & $\begin{array}{c}\text { In-person } \\
\text { early voting }\end{array}$ \\
\hline CT & No & No \\
DE & No & No \\
MD & Yes & Yes \\
NH & No & No \\
NJ & Yes & No \\
NY & No & No \\
PA & No & No \\
RI & No & No \\
VA & No & No \\
WV & Yes & No \\
\hline
\end{tabular}

Source: National Conference of State Legislatures, 2012. 
significant opportunities to vote before Election Day by mail or in-person (see Table 1).

The attributes of openness and centralization associated with in-person early voting, Election Day vote centers, provisional and mail-in voting can be applied to the operation of Election Day precinct polling. Openness allows individuals to vote at any location throughout the county rather than be restricted to voting at only one location near the voter's residence. As noted above, wherever a voter chooses to ballot on or before Election Day, they receive an appropriate ballot for where they reside in the jurisdiction. Consequently, it is not possible for a person eligible to vote in a jurisdiction to vote at the wrong polling place in that jurisdiction. Of course voting in the wrong jurisdiction (i.e., county) is still possible, but with in-person early voting and/or Election Day vote centers, not being registered in a specific precinct and voting place location is not possible. Mail-in voting provides the greatest flexibility in terms of where and when voters ballot. The obstacle to mail-in voting is obtaining and returning the mail-in ballot, conditions influenced by state mandated deadlines for requesting and returning mail ballots and the availability of postal service. Local election officials have considerable flexibility in allowing voters to cast and count a provisional ballot when they lack identification or attempt to vote at the wrong polling place.

Centralization refers to the accessibility of polling places to where voters not only reside, but where they work, shop, recreate, and travel. A small number of larger polling places define a centralized voting system. Stein and Vonnahme (2008) found that larger and more visible polling sites can reduce informational costs that voters incur when attempting to find a polling location. A larger number of parking spaces, voting machines, and poll workers reduce voters' time to vote. With more staff at each polling location, poll workers are able to specialize in certain tasks such as checking in voters or assisting them with their ballots, which should lead to more efficient operations and improved service to voters. In case of natural disasters and emergencies we might expect larger and more centrally located polling places (e.g., hotels, supermarkets, stadia, and larger public buildings) to be more accessible and powered in the aftermath of a natural disaster.

I expect that the features of openness and centralization associated with mail-in, early voting, and Election Day vote centers will be more effective at mitigating the consequences of natural disasters on measures of electoral administration and performance (e.g., turnout). In addition, the flexibility local officials can exercise in accepting and counting provisional ballots when voters show up at the wrong polling place, with insufficient identification, and fulfill requests for mail-in ballots outside of prescribed dates and qualifications is expected to lessen the negative effect natural disasters have on voter turnout. Out of necessity a smaller number of larger polling places may have been substituted for a larger number of smaller sized and equipped polling places in aftermath Hurricane Sandy, also lessening the negative effect Sandy had on voter turnout.

\section{ELECTION ADMINISTRATION AND PERFORMANCE DURING HURRICANE SANDY}

To assess the impact of Hurricane Sandy on the conduct and administration of the 2012 Presidential election I have compiled measures at the county level $(\mathrm{N}=3,000+)$ on several indicators of electoral performance including: voter turnout, absentee voting, early voting, provisional votes cast, provisional votes counted, and the number of polling places and poll workers. These data are mostly culled from the Election Assistance Commission's (EAC's) 2008 and 2012 Election Administration and Voting Survey of local election administrators. ${ }^{3}$ Identification of those counties $(\mathrm{N}=220)^{4}$ that received a

\footnotetext{
${ }^{3}$ My analysis is based on a "preliminary draft" of the 2012 Election Assistance Commission (EAC) Election Administration and Voting Survey data file. There are several omissions in these data. Early votes cast in Georgia counties are reported as mail-in votes and early votes in Texas are reported as the number of early voting place locations rather than the vote cast early. Early votes cast in Texas were obtained from the Texas Secretary of State's website. My thanks to Charles Stewart for providing me with absentee and early votes cast by county for Georgia. In 2008 New York State did not provide county level responses to the EAC's Election Administration and Voting Survey. Data on voter turnout and registration in 2008 for New York State counties are available from the New York State Board of Elections' website, <http://www.elections .ny.gov/ $>$. Other measures of electoral performance reported in the EAC's survey are not available for New York State Counties in 2008. I have used 2010 measures of electoral performance in place of 2008 measures for New York State Counties $(\mathrm{N}=62)$, available from the 2010 EAC's Election Administration and Voting Survey.

${ }^{4}$ Four counties in Virginia that received a FEMA disaster declaration did not respond to the 2012 Election Assistance Commission's survey.
} 
disaster declaration, my measure of the severity of Hurricane Sandy in each U.S. county, were obtained from the FEMA website. ${ }^{5}$

\subsection{Descriptive findings}

Turnout declined on average $2.8 \%$ (T-value $=4.8$, $\mathrm{P}<.000$ ) between 2008 and 2012 in counties in which disaster declarations were issued for Hurricane Sandy. Voter turnout declined only .8\% in all other U.S. counties. There was no significant change in mail-in absentee voting in either counties adversely affected by Hurricane Sandy or those counties not severely impacted by the hurricane. Moreover, its noteworthy that absentee voting is considerably lower in counties adversely affected by the hurricane $(5 \%)$ compared to all other counties $(18 \%)$. This finding is largely due to the absence of no-excuse absentee mail-in voting in most states impacted by Hurricane Sandy (see Table 1).

Early voting increased significantly in unaffected counties between 2008 (14\%) and 2012 (16\%), while also increasing by $2 \%$ in counties most adversely affected by Hurricane Sandy. We suspect this latter change is related to the implementation of in-person early voting in Maryland for the 2012 presidential election, the only state among those affected by Hurricane Sandy to allow voters to ballot in-person early in the 2012 election (see Table 1).

On average the proportion of provisional ballots cast in counties adversely affected by Hurricane Sandy increased from .005 in 2008 to .008 in 2012. The proportion of provisional ballots counted, however, remained unchanged between 2008 (.550) and 2012 (.551) in the same counties. Among counties spared the worst effects of Hurricane Sandy provisional voting also increased between 2008 (.004) and 2012 (.006) but the share of provisional votes counted in these counties dropped on average from .329 to .288 .

As expected the number of polling places declined in counties most adversely affected by Hurricane Sandy. In 2008 these counties operated 1.1 polling places per 1,000 registered voters; in 2012 this figure declined to 1.0 polling places per 1,000 registered voters, a statistically significant change in the number of polling places $(\mathrm{P}<.05)$. Whether intentional or forced by Hurricane Sandy, counties in which Hurricane Sandy inflicted its greater damage experienced a significant consolidation of voting place locations. Counties unaffected by Hurricane Sandy operated 1.1 and 1.1 polling places per 1,000 registered voters in 2008 and 2012 respectively. The number of poll workers per polling place increased in all counties between 2008 and 2012, but this increase was significantly greater in counties adversely affected by Hurricane Sandy. In these counties the number of poll workers per polling place grew from 4 to 4.6 , compared to a .42 increase in the number of poll workers per polling place among all other U.S. counties. Polling place operations changed in disaster counties in a manner that might have mitigated the decline in voter turnout observed in these counties between the two presidential elections.

\subsection{Modeling voter turnout during Hurricane Sandy}

To test the efficacy of these mitigating actions on election performance in 2012, I estimated a model of voter participation in the 2012 presidential election that allows me to isolate the effects of Hurricane Sandy and other determinants of turnout including early voting, absentee voting, provisional voting, the number of polling places and poll workers. The estimates of turnout in the 2012 presidential election include terms for the interaction between each determinant and a county's location inside and outside an area severely affected by Hurricane Sandy. In addition, dummy variables for each county's state location are included in the model (i.e., a fixed-effects model) to control for a number of omitted state level factors that might account for turnout (e.g., the state's electoral competitiveness). I also weighted each observation by the number of ballots cast, counting each vote equally, preventing the results from being skewed by a larger number of smaller jurisdictions with a few voters.

Table 2 reports the regression estimates for voter turnout in 2012 (coefficients for state dummies are not reported). The estimates for the interaction terms identify the effects of each determinantearly voting, absentee voting, provisional voting, and polling place practices - on turnout in counties that received a disaster declaration from FEMA. The main effects for these variables represent their impact on voter turnout in counties that did not receive a FEMA disaster declaration for Hurricane Sandy.

\footnotetext{
${ }^{5}<$ http://www.fema.gov/disasters/ $>$.
} 
Table 2. Regression Estimates for 2012 Voter TURNOUT (\%) (Robust StANDARD ERRORS)

Turnout $2008(\%)$

Disaster declaration $(0,1)$

Effects in non-disaster counties

Early vote $(\%)$

Absentee vote (\%)

Provisional vote $(\%)$

Log of Poll places per vote

Effects in disaster counties

Early vote * Disaster (\%)

Absentee vote $*$ Disaster $(\%)$

Provisional vote * Disaster $(\%)$

Log of Poll places per vote $*$ Disaster

Constant

Observations

$R$-squared

A fixed effects model was estimated. Coefficients for state dummy variables not reported and are available from the author.

$* * * p<0.01,{ }^{* *} p<0.05, * p<0.1, \# p<.1$ (one-tailed)

The fixed effects model accounts for $66 \%$ of the variation in county level voter turnout in the 2012 Presidential election. As expected, voter turnout in the 2008 presidential election is strong predictor of 2012 turnout. Both elections featured a competitive presidential contest with Barack Obama as a candidate in both elections. The effect of Hurricane Sandy on voter turnout is expectedly negative but not statistically significant at conventional levels $(\mathrm{P}=.1)$.

Among counties not adversely affected by Hurricane Sandy none of the alternative modes of casting a ballot including in-person early voting, mail-in voting, and provisional voting had significant and expected effect on voter turnout. These findings are not unexpected; few researchers have found a significant turnout effect from any of mode of convenience voting (Burden et al. 2014; Gronke et al. 2007; Stein 1994; Berinsky 2005; Hanmer and Traugott 2004; Kousser and Mullin 2007). Similarly the number of voting places per voter, that is a smaller number of large sized polling places, has an expected negative effect on turnout, but again this effect is not statistically significant $(\mathrm{P}>.05)$.

Among counties impacted by Hurricane Sandy the availability of alternatives to Election Day balloting had a mixed effect on voter turnout. Absentee mail-in voting had a significant and unexpectedly negative effect on voter turnout in counties impacted by Hurricane Sandy. As noted above absentee mail-in voting is restricted in seven of the ten states most severely affected by Hurricane Sandy. I suspect that any increase in absentee voting in these states was an indication that Election Day voting was problematic for many voters as they sought to obtain and cast a mail-in absentee ballot. In states with no-excuse absentee voting and with adequate time before Election Day to obtain an absentee ballot, a larger proportion of ballots cast by mail would predict a higher total vote turnout. This was clearly not the case in hurricane-impacted counties. In these jurisdictions there was neither sufficient time nor flexibility in the law to enable all those voters who wanted to vote by absentee mail-in ballot to do so.

The proportion of the vote cast by in-person early voting had a significant and expected positive effect on voter turnout in counties most adversely affected by Hurricane Sandy. A one percent increase in the vote cast early increased turnout by $.23 \%$. Of course, this effect is limited only to counties in Maryland, the only state that allowed in-person early voting in 2012.

Provisional voting is significantly related to lower voter turnout in counties most adversely affected by Hurricane Sandy. Recall these counties experienced a significant increase in the proportion of provisional ballots cast between 2008 and 2012, but not an accompanying increase in the proportion of provisional ballots counted between the two presidential elections. I suspect that many persons whose lives were disrupted by Hurricane Sandy were unable to vote at their designated Election Day polling place or lacked sufficient identification resulting in having to cast a provisional ballot that may not have been counted by election officials in counties affected by Hurricane Sandy.

The consolidation of polling places observed in counties adversely affected by Hurricane Sandy had a positive effect on voter turnout in these counties. Recall that there is evidence that a smaller number of larger polling places more centrally located where voters work, shop, and travel enhances voter turnout. Though this relationship is observed in all counties, it is demonstrably stronger in those counties most severely affected by Hurricane Sandy. Figure 1 reports the expected proportion of voters who voted in the 2012 by the number (log) of polling places per voter, holding all other independent variables at their mean values for counties affected and unaffected by Hurricane Sandy. For both populations of counties polling place centralization has a negative and linear effect 
a

Non-disaster counties

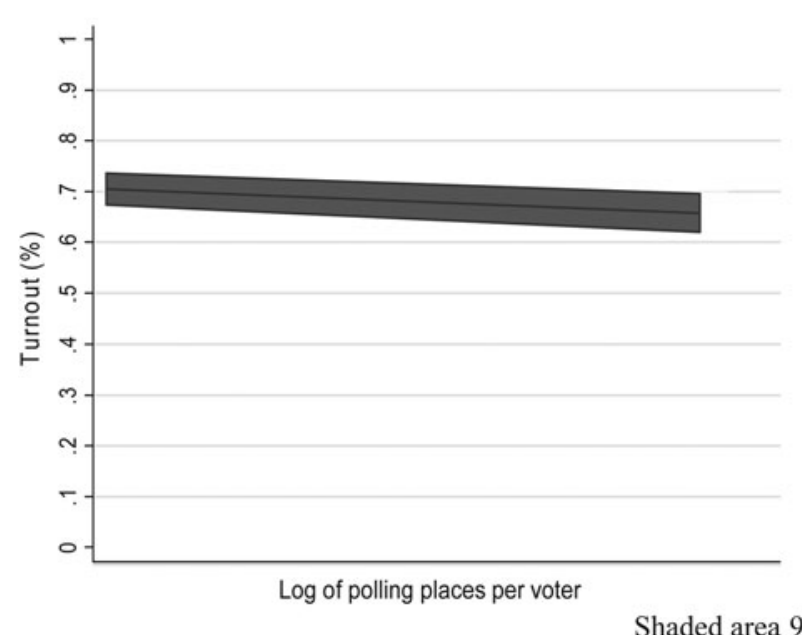

b

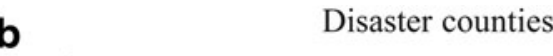

FIG. 1. Predicted 2012 voter turnout. Shaded area 95 confidence interval.

on the proportion of registered voters who participated in the 2012 election. Counties where the hurricane imposed its greatest damage, however, have a steeper and statistically significant $(\mathrm{P}<.05)$ rise in turnout where there was the greatest concentration of voters per polling place. This effect may not have been intentional or orchestrated by local election officials in these counties. It is possible that the only facilities accessible to voters and with power were larger and more centrally located polling places such as schools, government buildings, and commercial/retail stores.

\section{CONCLUSIONS AND GENERALIZATIONS}

It is difficult to draw strong conclusions and generalizations for how local election officials should respond to and prepare for natural disasters from the study of a single election. In many respects the election of 2012 in those areas hit by Hurricane Sandy was a success; the election was held and there were no obvious doubts about its outcome arising from the hurricane. Many of the correctives for the disruptive affect Hurricane Sandy had on the 2012 election reside with individual state legislatures, not local election officials. Providing voters with greater flexibility when, where, and how they cast their ballots (i.e., absentee mail-in voting, inperson early voting, and Election Day vote centers) are choices only state legislatures can make, not county officials charged with conducting and administering elections. Moreover, many of these electoral reforms (e.g., in-person early voting) are the subject of recent and intense partisan debate and are not likely to be adopted in many states, even where their adoption might significantly mitigate the disruptive impact natural disasters can have on elections.

I did identify one practice that local election officials might readily adopt without much controversy as they prepare for and respond to the threat posed by natural disasters and emergencies. Polling place practices, specifically the number, staffing, and location of where voters ballot on or before Election Day, has been shown to have a positive effect on voter participation. A note of caution about this finding and the presumed recommendation for a smaller number of larger polling places. I have assumed a smaller number of larger polling places are also associated with their location in areas more central to where voters work, shop, and travel; places that are more convenient and accessible than residentially proximate polling places. Moreover, I have assumed that a smaller number of larger polling places increases the efficiency of polling place operations, a finding reported in other studies.

In this study I do not report nor do I know the location of polling places, nor do I have data about polling place performance (e.g., waiting 
time). Polling place locations are constrained by the availability of facilities and their cost. Not all of the most efficacious locations for polling places are available for use on or before Election Day. Future research needs to examine the location of polling places and their cost of operation before recommending consolidation of polling places as an antidote for the potential negative impact of natural disasters and emergencies on elections.

\section{REFERENCES}

Berinsky, Adam. 2005. "The Perverse Consequences of Electoral Reform in the United States, American Politics Research 33(3): 471-491.

Berinsky, Adam, Nancy Burns, and Michael Traugott. 2001. "Who Votes by Mail? A Dynamic Model of the Individual-Level Consequences of Vote-By-Mail Systems." Public Opinion Quarterly 65(2): 178-197.

Brady, Henry E. and John E. McNulty. 2011. "Turnout Out to Vote: The Costs of Finding and Getting to the Polling Places." American Political Science Review 105: 115-134.

Burden, C. Barry, David T. Cannon, Kenneth R. Mayer, and Donald P. Moynihan. 2014. "Election Laws, Mobilization, and Turnout: The Unanticipated Consequences of Election Reform." American Journal of Political Science 58: 95-109.

Brooks, John and John Henderson. 2012. "Rain and Representation: The Effect of Margin of Victory on Incumbent Legislative Behavior."

Cemenska, Nathan, Jan E. Leighley, Jonathan Nagler, and Daniel P. Tokaji. 2009 Report on the 1972-2008 Early and Absentee Voting Dataset. A reported prepared for the Pew Charitable Trusts.

Gatrell, J. D. and Bierly, G. D. 2002. "Weather and Voter Turnout: Kentucky Primary and General Elections, 1990-2000.” Southeastern Geographer 42: 114-34.

Gimpel, James and Jason Schuknecht. 2003. "Political Participation and the Accessibility of the Ballot Box." Political Geography 22(4): 471-488.

Gomez, Brad, Thomas G. Hansford, and George A. Krause. 2007. "The Republicans Should Pray for Rain: Weather, Turnout, and Voting in U.S. Presidential Elections." Journal of Politics 69: 649-663.

Gronke, Paul, Eva Galanes-Rosenbaum, and Peter Miller. 2007. "Early Voting and Turnout." PS: Political Science and Politics 40: 639-645.

Hanmer, Michael and Michael Traugott. 2004. "The Impact of Voting by Mail on Voter Behavior." American Politics Research 32(4): 375-405.

Hansford, T. G. and Gomez, B. T. 2010. "Estimating the Electoral Effects of Turnout." American Political Science Review 104(2): 268-288.

Haspel, Moshe and H. Gibbs Knotts. 2005. "Location, Location, Location: Precinct Placement and the Costs of Voting." Journal of Politics 67(2): 560-573.
Karp, Jeffrey and Susan Banducci. 2001. "Absentee Voting, Mobilization, and Participation.” American Politics Research 29(2): 183-195.

Kimball, David C., Chris T. Owens, and Katherine M. Keeney. 2004. "Unrecorded Votes and Political Representation." In Counting Votes: Lessons from the 2000 Presidential Election in Florida, ed. Robert P. Watson, Gainesville: University Press of Florida, 135-50.

Knack, S. 1994. "Does Rain Help the Republicans? Theory and Evidence on Turnout and the Vote." Public Choice 79: 187-209.

Knack, Stephen and Martha Kropf. 2003. "Voided Ballots in the 1996 Presidential Election: A County-Level Analysis." Journal of Politics 65: 881-98.

Kousser, Thad and Megan Mullin. 2007. "Does Voting by Mail Increase Participation? Using Matching to Analyze a Natural Experiment." Political Analysis 15(4): 428-445.

Laskowski, S. J., M. Autry, J. Cugini, W. Killam, and J. Yen. 2004. Improving the Usability and Accessibility of Voting Systems and Products. NIST Special Publication 500-256.

Leighley, Jan E. 2008. "Commentary on Attitudes, Opportunities and Incentives: A Field Essay on Political Participation." Political Research Quarterly 51: 46-49.

Ludlum, D. 1984. The Weather Factor. Houghton Mifflin Company, Boston, MA.

McNulty, John, Conor Dowling, and Margaret Ariotti. 2009. "Driving Saints to Sin: How Increasing the Difficulty of Voting Dissuades Even the Most Motivated Voters." Political Analysis 17(4): 435-455.

Michael P. McDonald. 2008. "The Return of the Voter: Voter Turnout in the 2008 Presidential Election." Forum 6(4): $1-10$.

National Conference of State Legislatures (NCSL). 2012. Absentee and Early Voting. < http://www.ncsl.org/ legislatures-elections/elections/absentee-and-early-voting .aspx $>$.

Neeley, Grant and Lilliard Richardson. 2001. "Who is Early Voting? An Individual Level Examination." Social Science Journal 38(3): 381-392.

Pew Charitable Trusts. 2012. Survey of the Performance of the American Electorate. Washington, D.C. < http://thedata .harvard.edu/dvn/dv/measuringelections $>$.

Oliver, J. Eric. 1996. "Who Votes at Home?: The Influence of State Law and Party Activity on Absenteee Voting and Overall Turnout." American Journal of Political Science 40(2): 498-513.

Richey, Sean. 2008. "Voting by Mail: Turnout and Institutional Reform in Oregon.” Social Science Quarterly 89(4):902915.

Shachar, Ron and Barry Nalebuff. 1999. "Follow the Leader: Theory and Evidence on Political Participation." American Economic Review 89(3): 525-547.

Southwell, Priscilla and Justin Burchett. 2000. "The Effect of All-Mail Elections on Voter Turnout." American Politics Quarterly 29(1): 72-80.

Southwell, Priscilla L. 2004. "Five Years Later: A Re-assessment of Oregon's Vote by Mail Electoral Process." PS: Politics and Political Science 98(1): 89-93.

Stein, Robert. 1998. "Early Voting.” Public Opinion Quarterly 62(1): $57-70$ 
Stein, Robert and Patricia Garcia-Monet. 1997. "Voting Early, But Not Often.” Social Science Quarterly 78: 657-677.

Stein, Robert and Greg Vonnahme. 2008. "Engaging the Unengaged Voter: Vote Centers and Voter Turnout." Journal of Politics 70: 487-497.

Stein, Robert and Greg Vonnahme. 2010. The Cost of Elections. Working Paper.

Stein, Robert and Greg Vonnahme. 2012b. "When, Where, and How We Vote: Does It Matter?" Social Science Quarterly 11:291-301.

Stein, Robert and Greg Vonnahme. "Polling Place Practices," Prepared for presentation at the Measure of Elections Conference, June 18-19, 2012, Massachusetts Institute of Technology, Boston, MA.
White, John. 1960. Voting Machines and the 1958 Defeat of Constitutional Revision in Michigan. Ann Arbor: University of Michigan Press.

Address correspondence to: Robert M. Stein Department of Political Science Rice University 6000 S. Main Houston, TX 77251

E-mail: stein@rice.edu 